Review

\title{
Application of the Socio-Ecological System Framework to Forest Fire Risk Management: A Systematic Literature Review
}

\author{
Ingrid Vigna ${ }^{1, *(\mathbb{D}}$, Angelo Besana ${ }^{1}$, Elena Comino ${ }^{2} \mathbb{D}$ and Alessandro Pezzoli ${ }^{1}$ \\ 1 Interuniversity Department of Regional and Urban Studies and Planning (DIST), Politecnico di Torino \& \\ Università di Torino, 10125 Torino, Italy; angelo.besana@unito.it (A.B.); alessandro.pezzoli@polito.it (A.P.) \\ 2 Department of Environment, Land and Infrastructure Engineering (DIATI), Politecnico di Torino, \\ 10128 Torino, Italy; elena.comino@polito.it \\ * Correspondence: ingrid.vigna@polito.it
}

Citation: Vigna, I.; Besana, A.;

Comino, E.; Pezzoli, A. Application of the Socio-Ecological System

Framework to Forest Fire Risk Management: A Systematic Literature Review. Sustainability 2021, 13, 2121. https://doi.org/10.3390/su13042121

Academic Editors

Isabel Banos-González and

Julia Martínez-Fernández

Received: 22 January 2021

Accepted: 11 February 2021

Published: 17 February 2021

Publisher's Note: MDPI stays neutral with regard to jurisdictional claims in published maps and institutional affiliations.

Copyright: (c) 2021 by the authors. Licensee MDPI, Basel, Switzerland. This article is an open access article distributed under the terms and conditions of the Creative Commons Attribution (CC BY) license (https:// creativecommons.org/licenses/by/ $4.0 /)$.

\begin{abstract}
Although increasing concern about climate change has raised awareness of the fundamental role of forest ecosystems, forests are threatened by human-induced impacts worldwide. Among them, wildfire risk is clearly the result of the interaction between human activities, ecological domains, and climate. However, a clear understanding of these interactions is still needed both at the global and local levels. Numerous studies have proven the validity of the socioecological system (SES) approach in addressing this kind of interdisciplinary issue. Therefore, a systematic review of the existing literature on the application of SES frameworks to forest ecosystems is carried out, with a specific focus on wildfire risk management. The results demonstrate the existence of different methodological approaches that can be grouped into seven main categories, which range from qualitative analysis to quantitative spatially explicit investigations. The strengths and limitations of the approaches are discussed, with a specific reference to the geographical setting of the works. The research suggests the importance of local community involvement and local knowledge consideration in wildfire risk management. This review provides a starting point for future research on forest SES and a supporting tool for the development of a sustainable wildfire risk adaptation and mitigation strategy.
\end{abstract}

Keywords: socio-ecological system; wildfire risk; spatial system modelling; participatory modelling; traditional knowledge; agent-based model

\section{Introduction}

The interconnection between forest ecosystems (as defined by the Convention on Biological Diversity, "a forest ecosystem is a dynamic complex of plant, animal and microorganism communities and their abiotic environment interacting as a functional unit, where trees are a key component of the system." [1]) and our socioeconomic systems is deep and unmistakable. During the past few decades, the importance of forests for our well-being has become increasingly clear. Growing concerns about climate change have brought forest ecosystems health to the attention of the public and policy makers. However, globally, forests faced an annual area loss of 4.7 million hectares between 2010 and 2020. Although regional trends are diverse, moreover, climate change, together with other human-induced changes, threatens forest ecosystems health even in the areas characterized by a net gain of forest surface [2].

In particular, wildfires are a significant result of the interaction between different sources of pressure on forest ecosystems. In 2015, fires affected 98 million hectares of forests worldwide [3]. Although most of the annual burned areas are in tropical regions, temperate forests are also affected by wildfires. In the United States, for example, the annual burned area due to wildfires increased by over $5 \%$ per year over the period 19912015 [4]. According to the European Forest Fire Information System (EFFIS), 58\% of the total burned area in Europe in 2018 was in forests and other wooded land, as identified by the CORINE Land Cover Type classification system [5]. In addition, climate change is 
predicted to cause an increase in the frequency of heat waves, dry spells, and consequently, droughts, especially in southern Europe. This, will exacerbate the length and severity of the fire season in the areas at risk and the probability of large fires [6].

The drivers of wildfire risk, however, are not limited to meteorological factors; vegetation conditions, such as the level of species richness, age distribution of trees, and human behaviour are all crucial factors [7]. Concerning human influence, forest management can reduce the risk of large forest fires by avoiding fuel accumulation, for example through the prescribed fire technique [8-10]. Moreover, the risk of wildfires is strictly linked to the distribution of population, land cover, and land use [7]. The Wildland-Urban Interface (WUI), which represents the border between the urban area and forests or open land, is a significant factor in forest fire ignitions [11,12]. Although in the Global South, deforestation is often due to human-caused burning with the aim of converting land to agriculture, in the Global North the desire to be close to nature results in an increase in the fire hazard and the vulnerability of people and infrastructure. Tourists are also potential causes of ignition, and the increasing recreational use of forests, together with the extension of the tourism season due to climate change, will probably increase the chances of fire [13]. Finally, rural abandonment is recognised as a cause of the exacerbated fire regime. Abandoned agricultural land typically goes through a phase of fallow land, with a high level of flammable vegetation, before turning into stable forests [14].

In view of the above, it is clear that the development of the socio-economic system has strong impacts on the ecological environment, whose disturbances, such as wildfires, in turn affect socio-economic organizations. A comprehensive understanding of the interactions between the diverse elements and their contribution to fire risk definition remains necessary at both the global and local levels [7,15-17], with reference to the characteristics of each specific region fire regime history $[14,18]$.

Socio-ecological system (SES) models are valid frameworks for the analysis of the interactions between humans and nature, namely the socio-economic and ecological dimensions. These systemic analysis tools rely on the characterisation of a comprehensive structure, which is defined by Glaser et al. [19] as "a complex, adaptive system consisting of a biogeophysical unit and its associated social actors and institutions. The spatial or functional boundaries of the system delimit a particular ecosystem and its problem context."

One of the major challenges faced by SES research is to close the gap between two different disciplinary approaches, integrating the typical quantitative data of ecological sciences with the qualitative data of social sciences [20]. For this purpose, many attempts of modelling the human-nature relationships and feedbacks have been made, ranging from graphical mental maps to mathematically formulated models (as an example, [21]). Subsequently, agent-based models (ABM) have been developed to integrate the dynamic spatial dimension [19,22-24].

SES research has had a strong development in recent years thanks to the rising interest in resiliency studies [25]. Previous studies have tried to summarise and compare existing theoretical frameworks for SES analysis. In particular, Binder et al. [26] selected and analyzed 10 frameworks based on 9 contextual criteria and 10 structural criteria, while Schlüter et al. [20] created a specific reference scheme for mapping the existing model types according to their degree of realism and integration.

However, as far as we know, little work has been done in reviewing previous studies specifically related to the forest ecosystem. Therefore, the aim of this work is to analyse the existing literature on the explicit application of SES frameworks to forest ecosystems, with a specific focus on wildfires. Object of the analysis are the interactions between the forest ecosystem, characterized by its dynamics of vegetation and in general of nature, and the socio-economic sub-system. This sub-system includes population dynamics and human activities, such as forest management and firefighting operations. Climate, which can be considered as an external factor to the socio-ecological system, also plays an important role in these interactions. 
The results of this literature review demonstrate the existence of a variety of methodological approaches and highlight some critical issues in forest fire management. Since the objective of this study is to provide wildfire researchers with a novel general overview of different approaches strengths and limitations, the structured discussion of the existing contributions is intended to be a robust baseline for future research in the forest SES. Moreover, this work can be a supporting tool for the development of an innovative sustainable wildfire management strategy, which addresses both the ecological and socioeconomic aspects of forest ecosystems as interconnected.

In the second section of this paper, the scientific databases chosen for the literature search and the method adopted for the analysis are described. The third section illustrates the main results, while the contributions of the studies are discussed in detail in the fourth. Finally, the last section summarises the principal outcomes and implications of this study.

\section{Method and Instruments}

A systematic literature review of the existing studies in English language on SES modelling for forest fire management was carried out. As presented in Figure 1, the adopted methodology consists of four steps, elaborated with PRISMA statement guidelines [27]:

1. Keywords search in scientific study databases;

2. First rough analysis of the results for the selection of relevant studies;

3. Analysis of the bibliographical references of the relevant studies for including additional studies;

4. Systematic analysis of the selected studies.

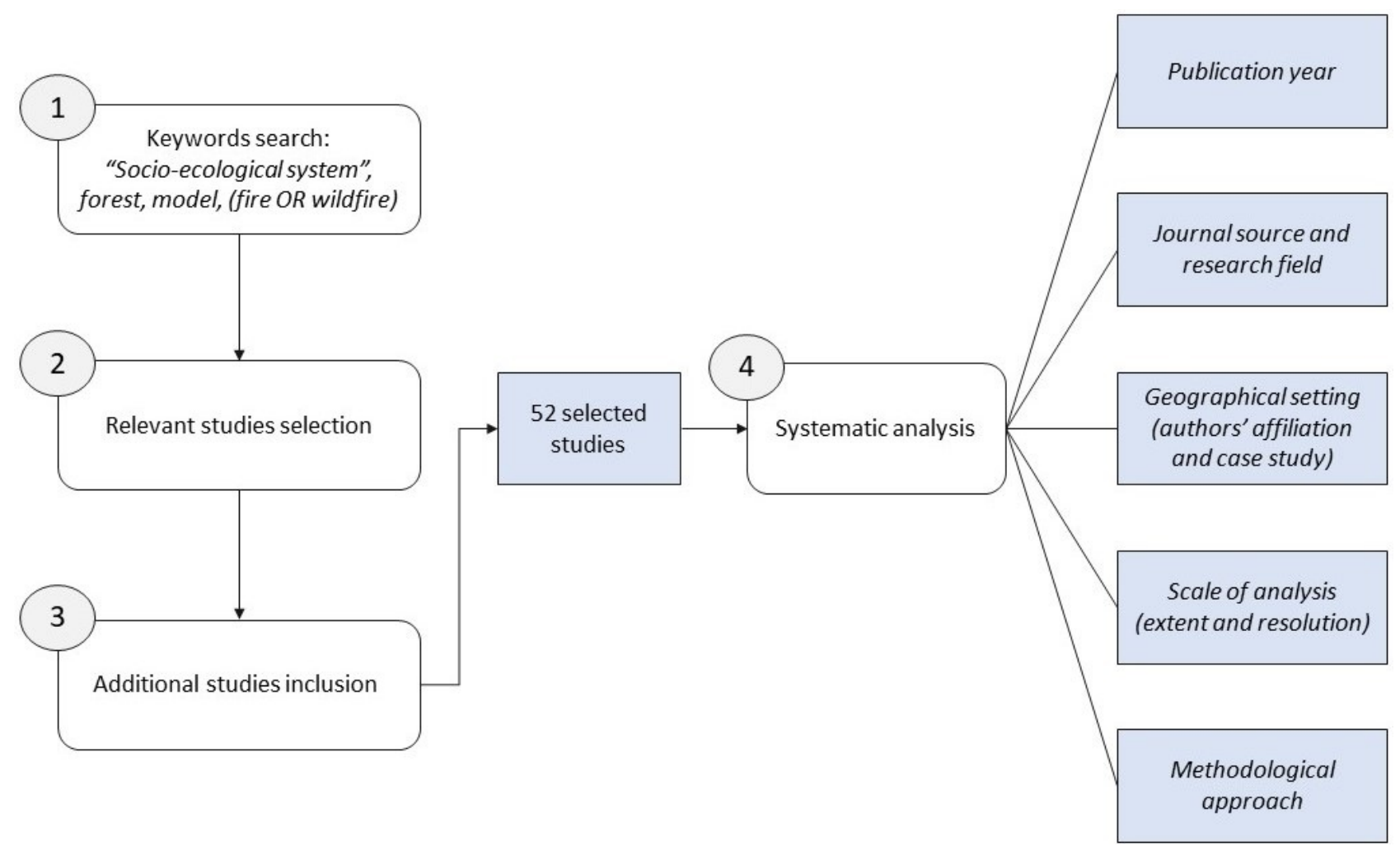

Figure 1. Scheme of the methodology adopted in this literature review.

\subsection{Keywords Search}

The first step was carried out using two academic search systems: ScienceDirect and Scopus. Both search tools are provided by Elsevier, and their multidisciplinary approach is considered a fundamental characteristic in the search tool choice [28]. The ScienceDirect digital archives contain approximately 2500 scientific journals published since 1823, while 
Scopus includes more than 24,600 active titles and has records going as far back as 1788 . For the sake of completeness, a supplementary search was carried out through the Web of Science Core Collection database, provided by Clarivate Analytics, whose oldest contents date back to 1970 .

Considering the SES modelling approach and the forest ecosystem, with a focus on wildfires, a slightly complex string was chosen:

"Socio-ecological system" AND forest AND model AND (fire OR wildfire)

The specificity of the combination of keywords was balanced by choosing the "all fields" search setting in all three databases. No initial time limit was indicated for the research, while only articles published by 31 December 2020 were considered.

The first step returned 412 studies from the Scopus system and 364 studies from the ScienceDirect system. In contrast, the supplementary search through the Web of Science Core Collection database returned only 10 studies. This is probably due to the different structure of the search tool, which is not suited for a narrow combination of keywords.

\subsection{Publications Selection}

In the second step, their titles and abstracts were analyzed to determine if they should be included in this literature review. The parameters considered were as follows:

- the consideration of both the ecological and socioeconomic spheres of the SESs;

- the forest ecosystem focus;

- mentioning wildfires either as the primary focus of the study or as one of the principal factors of the SES analysis.

This screening allowed us to reduce the list to 47 works in total.

\subsection{Snowball Inclusion}

In the third step, following a snowball approach [29], the cited references of the selected studies were analyzed. The same parameters elaborated for the second step were applied. This phase led to the inclusion of 5 other relevant studies that did not appear in the database search. Their absence in the first list of results could be because they were not listed in the searched databases or lacked the selected keywords in the paper text. For example, the term "Coupled Human Natural System (CHNS or CHANS)" was determined in some studies to be nearly synonymous with SES [30-32].

\subsection{Publications Analysis and Categorization}

During the fourth step, the 52 studies of the final list were analyzed regarding several aspects. First, the distribution of publications throughout the year illustrated the evolution of the interest in this research field over time. Then, the studies were classified according to their journal sources, which in turn were classified according to their scientific area of study (a complete table of the correspondence between the journals and the scientific areas is provided in Appendix A). The geographical origin of the authors and the geographical focus of the studies were investigated and represented using two cartographical products. The extent of the analysis adopted in the studies was classified into four scale classes based on an elaboration of Haggett [33]:

1. Microscale, corresponding to an urban scale (between $1.25 \mathrm{~km}$ and $12.5 \mathrm{~km}$ )

2. Mesoscale, corresponding to a subnational scale (between $12.5 \mathrm{~km}$ and $125 \mathrm{~km}$ )

3. Macroscale, corresponding to a national scale

4. Megascale, corresponding to a supranational scale.

The objective of the chosen classes was to consider the institutional division of space, which is a significant factor in the socioeconomic aspects of the SESs. For the studies that were carried out through a spatially explicit approach, the minimum grain chosen for the analysis was also considered, resulting in further classification of their resolution types.

Finally, the studies were classified according to their methodological approach. The methodological categories were not decided a priori, but they were identified through a 
qualitative analysis of the papers, with particular attention to their methodological sections. An iterative process was conducted: each time a new approach was identified, a new category was created. At the end of the process, the classification was revised in order to homogenize and simplify it by eliminating redundant categories.

This methodological classification was intended to be a useful instrument for guiding readers through different existent approaches and for suggesting specific study areas. The strengths and limitations of each approach are described in the Discussion section. However, the investigation presented here is not limited to this strict categorization, aiming at a more complex analysis. Therefore, the discussion of the contributions seeks to relate the diverse aspects of this study's outcomes, with particular attention on the geographical perspective, and to analyse the crucial forest fire management issues arising from the literature review.

\section{Results}

Fifty-two studies constitute the final list used for this literature review. Their complete list is reported in Appendix B, including the publication type, the authors' geography, the area of interest, the scale of analysis, and the methodological category.

According to the publication typology, five of the studies were literature reviews, one was classified as a short survey, and the rest were research articles. As illustrated in Figure 2, more than half of the papers were published after 2016, with a growing yearly trend. Although a declining trend is visible for the two last years, the graph highlights the recent interest in this research topic.

\section{Number of studies published per year}

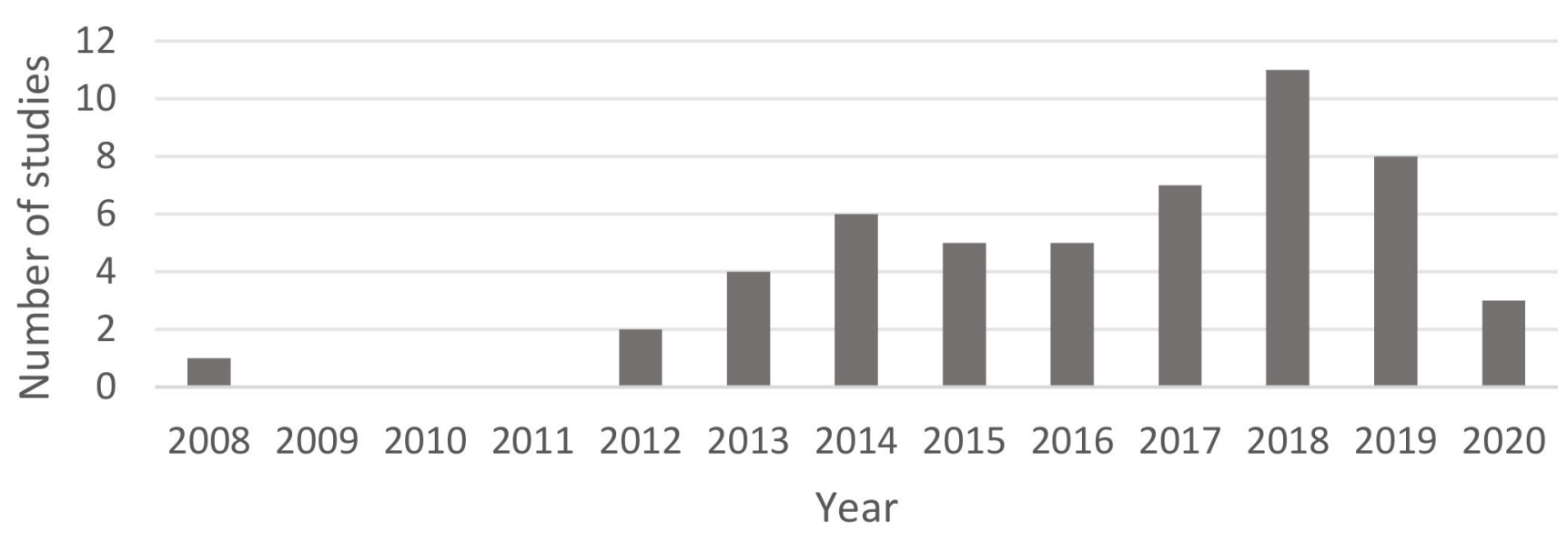

Figure 2. Distribution of the selected studies according to their publication year.

The source analysis revealed the scientific journals in which most of the articles were published. As listed in Table 1, these are Ecology and Society, with five papers, and Journal of Environmental Management, with four papers, followed by Ecological Indicators, Landscape and Urban Planning, and Sustainability, with three articles each. The journals were classified according to their primary scientific area. The results indicate that environmental science and ecology are undoubtedly the areas with the highest number of selected articles, followed by planning (see Table 2). 
Table 1. Most frequent journal sources for the selected studies and related number of published articles. A complete list of the journal sources is provided in Appendix A.

\begin{tabular}{cc}
\hline Most Frequent Journal Sources & Number of Published Articles \\
\hline Journal of Environmental Management & 5 \\
Ecology and Society & 4 \\
Ecological Indicators & 3 \\
Landscape and Urban Planning & 3 \\
Sustainability (Switzerland) & 3 \\
\hline
\end{tabular}

Table 2. List of the scientific areas of the journal sources of the selected articles. A complete table of the correspondence between the journals and the scientific areas is provided in Appendix A.

\begin{tabular}{cc}
\hline Scientific Area & Number of Related Studies \\
\hline Environmental science & 16 \\
Ecology & 13 \\
Planning & 6 \\
Forestry & 4 \\
Ecosystems & 3 \\
Sustainability & 3 \\
Agriculture & 2 \\
Biology & 1 \\
Risks & 1 \\
Various & 1 \\
Water & 1 \\
Wildfire & 1 \\
\hline
\end{tabular}

Figure 3 provides an overview of the number of studies published per country. The analysis of the geographical origin of the authors of the works established that the United States tops the list, with 17 studies published by at least one scientist affiliated with their institutions. The United States is followed by Italy with 14 studies, Spain with 9 studies, Greece with 8 studies, and Portugal with 7. Figure 4 shows the geographical focus of the study. The same five countries are the most frequent: Spain with 10 studies, the United States with 8, Greece with 7, and Italy and Portugal with 6 each. In addition, two more studies focusing on the entire Mediterranean region were considered in the count of studies focusing on Spain, Portugal, Greece, and Italy.

The scale of analysis adopted in the studies was analyzed with reference to the extent and the resolution. Table 3 provides the classification of the studies according to their scale extent.

Table 3. Classification of the selected articles according to the extent of analysis adopted. The scale classes are based on Haggett [33].

\begin{tabular}{cc}
\hline Scale of Analysis: Extent & Number of Studies Published \\
\hline Microscale & 3 \\
Mesoscale & 34 \\
Macroscale & 9 \\
Megascale & 4 \\
Various scales & 1 \\
Not defined & 1 \\
\hline
\end{tabular}

The resolution, in the form of the minimum grain chosen for the analysis, could be evaluated for the 32 studies that adopted a spatially explicit approach. Different types of resolutions were adopted, with most of the articles using a cartographical resolution expressed in degrees or in linear units. Others based their spatial subdivision on administrative borders, such as municipalities and prefectures. Several works have used homogeneous landscape subdivisions, such as the individual landscape decision units 
(IDUs) employed for ABM. Finally, only one study was based on natural borders, namely hydrogeological basins.

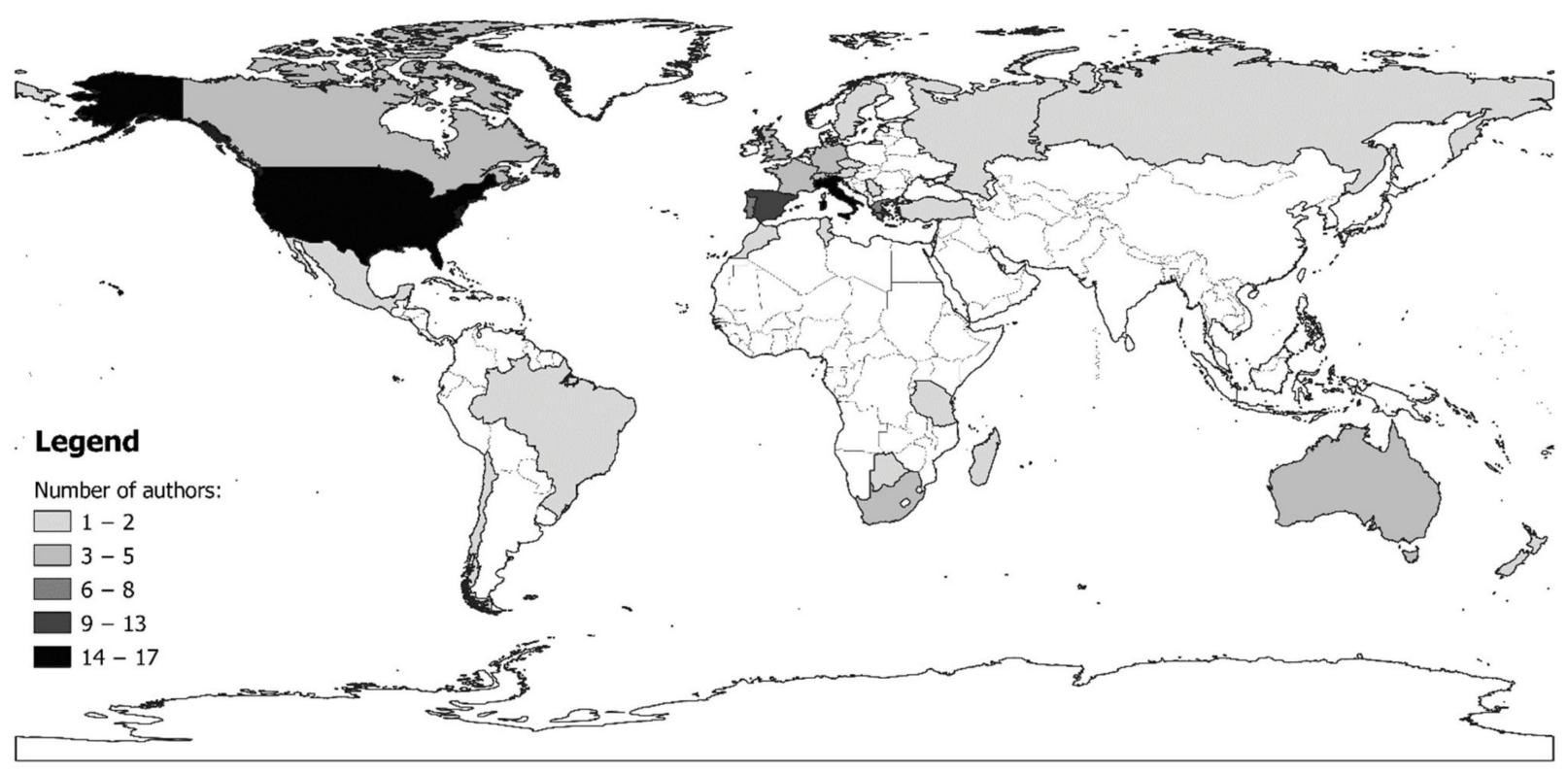

Figure 3. Distribution of the geographical origin of the authors of the selected studies. The number of authors per country is calculated as the number of studies which have at least one author affiliated with a research institution located in the selected country.

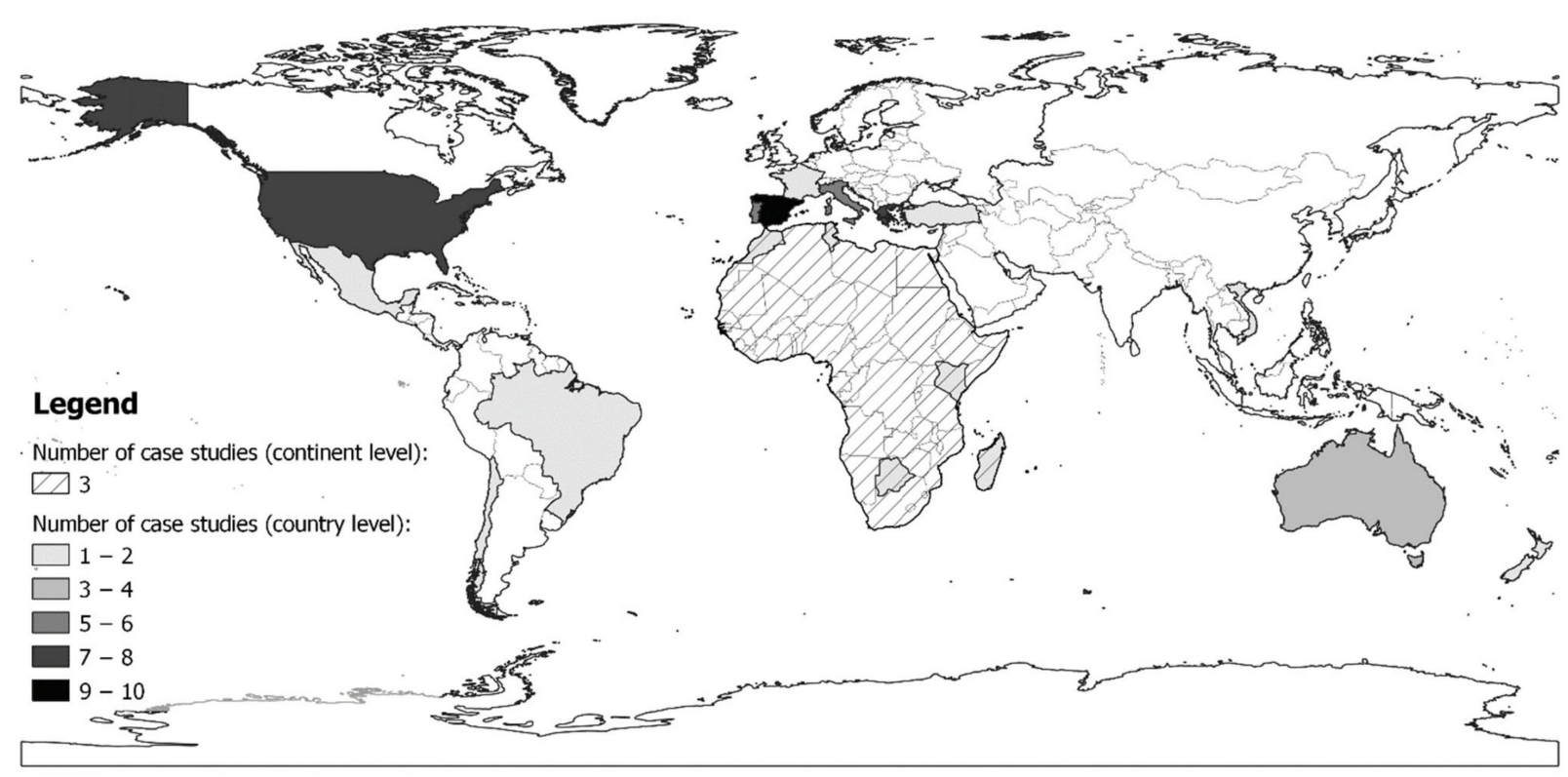

Figure 4. Distribution of the selected studies according to their geographical focus. For the studies with a national or subnational scale, the entire country is considered. For the studies with a supranational scale, the entire continent is considered. Please note that two studies focusing on the entire Mediterranean basin could not be represented. Moreover, four studies do not have a restricted geographical focus, so they were also excluded.

Concerning the methodology adopted in the 52 selected studies, 7 methodological categories resulted from the analysis of their approaches. They are briefly described and exemplified below: 
1. Qualitative approach (QA) category, analysing the SESs using different techniques, which are limited to their qualitative aspects (e.g., Balzan et al. [34] used an expert consultation for identifying the key characteristics of Mediterranean SESs and the current pressures on their ecosystem services).

2. Social science techniques (SST) studies, mostly using social science techniques for the participatory modelling of the socio-ecological systems (e.g., Bodonirina et al. [35] involved the local community of Zahamena forest in defining a shared mental model of the forest SES, in order to promote the discussion about resource management).

3. Statistical approach (SA) category, applying diverse statistical techniques to determine the quantitative relationships between different elements of the SESs (e.g., Ferrara et al. [36] investigated the linear and non-linear correlation among socio-economic variables and wildfires distribution).

4. Vulnerability analysis (VA) category, applying a vulnerability analysis technique (e.g., Aretano et al. [37] used a conceptual linear model of vulnerability for mapping vulnerable areas to fire risk and identifying effective management interventions).

5. Agent-based models (ABM) category, representing and analysing SESs through spatially explicit agent-based models (e.g., Spies et al. [32] used an agent-based landscape model for simulating future fire scenarios according to different management strategies).

6. Historical perspective (HP) category, employing a historical-archaeological perspective for the analysis of human-nature interactions (e.g., Power et al. [38] linked methods from behavioural and landscape ecology for evaluating past and predicting future legacies of human-fire on landscapes).

7. Quantitative modelling $(\mathrm{QM})$ category, providing a quantitative analysis of the interactions between the elements inside the SESs. Unlike the studies in the SA category, these are based on a comprehensive approach, modelling the SES elements and interactions in their entirety (e.g., Collins et al. [39] used a system dynamics model for analysing the interactions between physical and political systems in forest fire management).

The number of studies falling into each category is reported in Figure 5 (for the methodological approach used in each study, see Appendix B).

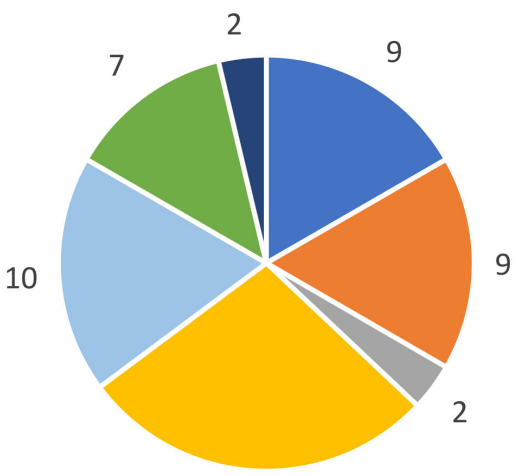

15

- Social Science Techniques (SST) - Qualitative Approach (QA)

- Historical Perspective (HP) $\quad$ Statistical Approach (SA)

- Quantitative Modelling (QM) = Agent-Based Models (ABM)

- Vulnerability Analysis (VA)

Figure 5. Methodological categories and related selected studies. Please note that one study is shared between the SST and the QA categories and one is shared by the HP and the ABM categories. For the methodological approach used in each study, see Appendix B. 


\section{Discussion}

The analysis of the 52 studies resulting from the scientific databases search provided evidence of the growing interest in SES analysis applied to forest fire management among scientists from different research fields. Most of the studies focused on areas within the United States and Mediterranean European countries-Italy, Spain, Portugal, and Greecewhose temperate forests are highly affected by forest fire dynamics. Most of the studies used a mesoscale extent of analysis, focusing on a portion of the country's territory whose dimensions are comparable with the SES dimensions.

The contributions of the analyzed studies are discussed in this section, with reference to the strengths and limitations of each chosen approach. Nevertheless, as mentioned before, the investigation proposed in this work is not limited to a strict methodological classification but is primarily intended to be a guideline for readers across the implied techniques. This section aims to relate the diverse aspects of the outcomes, with particular attention on the geography. As an illustration, this interrelated approach allowed us to identify two main research groups among the authors, those working on the Mediterranean Europe biome and those focusing on USA temperate forests. Moreover, the analysis highlighted some crucial forest fire management issues, which are reported and discussed.

\subsection{Qualitative Approaches}

A fundamental step in implementing an SES approach involves defining the characteristics of the targeted SES. A considerable number of the works analyzed had the aim of describing the SES dynamics from a purely qualitative point of view. However, diverse theoretical frameworks were employed. Balzan et al. [34], for example, used the Drive-Pressure-State-Impact-Response (DPSIR) framework [40,41], which is based on the idea that socioeconomic drivers exert pressure on the environment, thereby affecting its ability to provide ecosystem services. Higuera et al. [42] preferred a resilience perspective, describing the characteristics of fire-prone landscapes through the lens of desirability and the probability of their state change. This study is in good agreement with the regime shifts approach of Luvuno et al. [43] and with the concept of wildfire risk as a socioecological pathology of Fischer et al. [44]. Olander et al. [45] also focused on ecosystem services, developing a process for the identification of the so-called Benefit-relevant indicators.

Fischer [46] highlighted the role of individual and group behaviours in forest landscapes, whose outcomes are only visible after a certain time lag, highlighting the nature of the cultural and social artefacts of today's forests. The forest SES, therefore, can be seen as a multilevel hierarchical set of systems, going from the level of an individual's interactions with the environment to the level of the institutional interventions. An additional level is constituted by the representation of forest SESs as open systems, in which internal and external processes are only slightly distinguishable. The same consideration of the interaction between different scales is presented by Tedim et al. [30] as fundamental in their conception of a Fire Smart Territory.

The studies in this category achieve the objective of deepening the relationships between the factors composing the forest SES and of providing a structured key to understanding the role they play in wildfire dynamics. However, wildfire research needs to combine this more speculative approach with a quantitative analysis of the reality in order to efficiently support fire management.

\subsection{Social Science Techniques}

Several authors have proposed participatory techniques with the aim of involving the local community in the process and considering their point of view.

In particular, Moskwa et al. [47] adopted the concept of narratives as "stories of human groups that coalesce into dominant themes for informing ways of thinking and acting." They proposed the generation of common narratives through participatory workshops, asking local stakeholders to share their experience in designing an SES model and identifying its main issues related to fire risk. Similarly, Bautista et al. [48] developed the 
PRACTICE protocol to integrate diverse participatory methods, with a special focus on collective learning, and Nguyen et al. [49] conceived the concept of group model building. Bodonirina et al. [35] adopted a two-step approach, based on the Companion Modelling (ComMod) technique [50] for developing a shared mental model of the Zahamena forest SES, followed by a tabletop role-playing game for exploring the complex interactions in the system and possible future scenarios. Even if the game is only a simplified model of reality, it allows participants to feel personally involved and to view the system as a whole, providing a powerful discussion platform.

Mixed qualitative and quantitative approaches were also adopted in some cases, with the aim of integrating mental SES models with empirical data [51-53]. Moreover, Maru et al. [54] attempted to support the community engagement process with a strong literature review concerning local climate change impacts, vulnerability, and resilience.

The rising interest in public participation can be defined as "a voluntary process whereby people, individually or through organised groups, can exchange information, express opinions and articulate interests, and have the potential to influence decisions or the outcome of the matter at hand" [55]. This rising interest is in line with the growing necessity to consider the social dimension of the sustainable management of forests, which has been a topic of discussion between forestry sector organisations since the 1980s [56]. In this framework, the collective management of resources has gained new attention from the scientific community. Related to this theme is the contribution of Monzón-Alvarado and Keys [57], who used a participatory approach for analysing local fire knowledge, practices, and outcomes. They focused on six ejidos, collectively managed lands in Mexico characterised by a rotating agricultural system, where fire is used as a land management tool. The analysis was based on the participatory mapping technique, asking the involved farmers to sketch maps of the plots' characteristics and fire ignition plans.

Other studies, even if not classified in the SST methodological category, dealt with forests as collective goods. Some addressed the forest management decisions of individual owners as opposed to the behaviour of organisational actors and the potential of shared strategies $[58,59]$. The ability of governments to address problems on a large geographical scale that involve diverse dimensions makes them extremely suitable for wildfire management [46]. Another concept mentioned in many studies is the role of traditional knowledge in managing forest fire risk. As in the ejidos collective systems described by Monzón-Alvarado and Keys [57], the traditional use of fire as an instrument of land management has been fundamental in many agricultural systems. Moreover, traditional ecological knowledge constitutes beneficial cultural capital for resilience development. The positive case of the involvement of Australian Aboriginal people in the fire management of protected areas is a clear example of the benefits derived from the integration of traditional wisdom in management strategies [54]. This collaborative approach should be the starting point for an approach shift in other contexts, such as in Europe. Here, the so-called "firefighting trap" has prevented the development of an appropriate fire prevention strategy by focusing all the energy on the suppression phase $[30,38,60]$.

In summary, through participatory techniques, wildfire researchers are able to directly involve the local community in forest management. Nevertheless, this approach is clearly linked to the scale of analysis, which makes it effectively suitable only for local or regional contexts.

\subsection{Statistical Approaches and Vulnerability Analysis}

Many of the studies for which the authors chose a mainly quantitative approach are based on the statistical analysis of the patterns of different types of variables, aiming at linking wildfire events or related environmental dynamics with natural and socio-economic characteristics. Most of the studies with this type of approach are linked to a group of Italian researchers who applied it to the Mediterranean environment [37,61-68]. Wildfires are a vital natural dynamic of a maquis biome and an emerging issue in other areas of Mediterranean countries, such as alpine regions. Climate change will unavoidably affect 
wildfire risk through drier and warmer seasons, mainly in Southern Europe, moving the high-risk area borders northward [7,69]. Nine out of the 15 studies classified in the Statistical Approach methodological category have been carried out with the collaboration of at least one author among Salvati (who participated in all 9), Carlucci, Colantoni, Corona, and Ferrara. Four of these studies focused on the Italian territory, four on Greek territory, and one investigated local case studies in five different Mediterranean countries.

In these studies, multivariate techniques, such as principal component analysis, Spearman correlations, stepwise multiple regression, non-parametric Mann-Whitney inference, hierarchical clustering, and canonical correlation analysis, were applied to a sample of indicators assessing the biophysical and socioeconomic conditions, with the aim of investigating the spatial relationships between them. The indicators referred to diverse thematic areas according to the specific focus of the work and varied in number. The work of Ferrara et al. [36] is particularly illustrative. The authors chose a set of 8 indicators describing wildfires events, 20 indicators describing forest characteristics, and 146 indicators describing the territorial context, with 6 research dimensions: population, labour market, economy, quality of life, agriculture, and environment. Their results demonstrated the influence of regional-scale socioeconomic conditions on local-scale wildfire patterns.

Further attributable to the Statistical Approach category is the study conducted by Salvati et al. [66] regarding desertification in Mediterranean countries. As mentioned before, fire risk is not always the primary focus of the research, but it is considered a key factor in all the selected studies. In this case, the authors chose a set of 40 indicators for the characterisation of their case studies and classified them into 9 dimensions, with 3 in the "water runoff and fires" category. A similar approach was adopted in a previous study by Salvati et al. [70] and by Aretano et al. [37], who mapped the land vulnerability through evaluation and combination of a number of quality indicators.

Moreover, not all the authors who chose a statistical analysis technique opted for a spatially explicit approach. For example, Carlucci et al. [63] preferred a time-series analysis, aiming at comparing the historical trends of Italian wildfire regimes and national socioeconomic and cultural transformations across the years.

However, the statistical techniques of the works described here, which are built on the empirical analysis of context indicators, are generally not supported by theoretical modelling of the SES considered. This make this kind of approaches really case-specific and make their results hardly transferable to different contexts and poorly adaptable to SES relationships development.

\subsection{Agent-Based Models and Historical Perspectives}

Another relevant and growing quantitative spatially explicit approach consists of ABM analysis, which was chosen for seven of the studies analyzed. Five studies are linked to a group of scientists from the United States [31,32,58,71,72], whose main contributors are Olsen, Spies, and White. They used the agent-based model Envision in central and southcentral Oregon to evaluate the outcomes of current forest management decisions on future forest fire dynamics. In this case, a complex analysis of the relationships and possible feedback loops between the elements of the SES was necessary. Moreover, the representation of the behaviours of various local factors was a considerably challenge in the research and required the involvement of scientists from anthropology, economics, environmental history, policy science, and sociology. Different approaches were used to develop the decision rules for each group based on their different characteristics [71].

Concerning the contributions to the development of an interdisciplinary approach, the work of Githumbi et al. [73] is also particularly interesting. The authors combined the $\mathrm{ABM}$ approach with the historical perspective approach, integrating the two into a multidisciplinary framework characterised by archaeological techniques and the analysis of documentary and oral historical sources. This type of approach is perfectly in line with the need to explore the characteristics of the different dimensions of SESs, which go beyond 
the boundaries of a single discipline and require the involvement of experts from many scientific fields.

\subsection{Quantitative Modelling}

Some authors measured the interactions between the elements of the forest SES inside a comprehensive framework, taking into account their complexity. Diverse methods were proposed in an attempt to integrate a quantitative approach with a systemic design of the wildfire issue.

Zucca et al. [74] proposed a structured procedure for the selection of indicators for global land degradation and desertification. They based the procedure on the Driving force-Pressure-State-Impact-Response (DIPSIR) framework, also recently explored in other comparable studies $[75,76]$. They combined the procedure with an issue-based causal representation, which is constituted by a set of causes and effects related to land degradation and desertification problems. The authors had clearly shaped their method according to the availability and accuracy of detailed data, which is a crucial issue, especially when dealing with different sources of data. Their research established 20 indicators and related global datasets.

The system dynamics model developed by Collins et al. [39] introduced balancing and reinforcing feedback loops within the model. The model defined two different subsystems, namely the political and physical systems, that interact with each other. By altering the variables, it was possible to simulate the future performance of the entire forest fire management system. However, the authors emphasised that the output of the model simulations could not represent real values and that a high level of uncertainty needs to be considered. A similar issue affected the work of Porto et al. [59], who used a simulated landscape instead of actual case studies to identify the best forest management intervals for optimising biodiversity levels and fire resistance in a multi-ownership context.

A significantly different approach was chosen by Fetzel et al. [77], who used the quantification of net primary production (NPP), measuring the biomass produced by plants in a year. The human impact on the ecosystem was measured through the Human Appropriation of Net Primary Production (HANPP) framework, which provides actual data of ecological energy flows [78,79]. Moreover, the study of Martínez-López et al. [80] constitutes a valuable attempt to provide a customisable ecosystem services model able to bridge the potential of a global model with the context-specific information of a real case analysis. Finally, Pais et al. [81] built a complex spatially explicit process-based model, called REMAINS, by combining different simulation models. They implemented it using the Spatially Explicit Landscape Event Simulator to obtain a powerful instrument not only for investigating the impact of fire management and land use changes on fire regime but also for quantifying its effect on biodiversity conservation and carbon sequestration. According to the authors, future developments of their model should also consider climate variability and a wider range of ecosystem services.

These quantitative modelling approaches have the strength to address SES dynamics in their complexity. However, they require high levels of modelling and computation expertise, which make them probably not always suitable for supporting fire management decision processes.

\section{Conclusions}

Forest ecosystems are currently threatened by human-related impacts worldwide. While forest fires are a natural dynamic of most forest biomes, climate change is expected to intensify wildfire risks during drier and warmer seasons in certain areas, such as Mediterranean Europe. Moreover, their occurrence and impacts are strictly linked to human activities, which range from land management to open-air tourism. Therefore, analysing wildfire risk in the framework of a comprehensive SES that includes both the ecological and socioeconomic perspectives is necessary. 
This systematic literature review examined the existing English-language studies on the application of the SES approach to forest fire risk and discusses their contributions to this research field. The results constitute a robust starting point for the development of further research in forest SES modelling.

Seven different methodological approaches were identified in the literature: social science techniques, qualitative approach, statistical approach, quantitative modelling, agent-based models, and vulnerability analysis. The United States and European Mediterranean countries were the most abundant based on the author contributions and locations of the case studies. In particular, a group of Italian researchers authored many interesting studies focusing on the Mediterranean biome, carried out through the statistical correlation analysis between ecological and socioeconomic variables. However, these studies lack background theoretical modelling of the system and were not able to capture the complex dynamics of the SES. Therefore, they accurately capture the relationships characterizing the current situation of the target SES, but their results are hardly applicable to other contexts. Furthermore, a group of scientists from the United States proposed an ABM methodology, which led them to develop a model with the Envision software for a case study in Oregon temperate forest. Further work needs to be done to assess the versality of this software. The application of this methodology in other contexts, such as Mediterranean countries, could allow testing of its appropriateness with other constraints, actors involved, and environmental characteristics. In addition, the work of Pais et al. [81] suggests the opportunity to combine different models specific to one type of dynamics, such as species distribution or carbon sequestration models, into a more complex and comprehensive framework.

The benefit of local knowledge and the traditional use of fire also emerged from the analysis of the selected studies. Moreover, participatory research approaches were found to be a useful instrument for addressing forest management issues through the lens of collective resource management. These techniques need to be further developed, for making the involvement of local community a not negligible aspect of wildfire research, including its knowledge about local natural dynamics and its requirements for land management.

Finally, this work confirmed the necessity of an interdisciplinary approach and of collaboration between experts from different scientific areas. The ability to consider both the ecological and socioeconomic aspects of forest SESs is fundamental in developing a local sustainable wildfire management strategy. Future research should aim at bridging the gap between the diverse methodological approaches, by delineating a forest SES analysis procedure able to combine initial qualitative investigations of SES dynamics with both quantitative analysis and participatory techniques.

Author Contributions: Conceptualization, I.V., A.B., E.C. and A.P.; methodology, I.V., A.B., E.C. and A.P.; formal analysis, I.V.; writing—original draft preparation, I.V.; writing-review and editing, A.B., E.C. and A.P.; supervision, A.B., E.C. and A.P. All authors have read and agreed to the published version of the manuscript.

Funding: This research received no external funding.

Institutional Review Board Statement: Not applicable.

Informed Consent Statement: Not applicable.

Data Availability Statement: No new data were created or analyzed in this study. Data sharing is not applicable to this article.

Conflicts of Interest: The authors declare no conflict of interest. 


\section{Appendix A}

Table A1. Correspondence table between the scientific journals on which the selected articles were published and their scientific area, as interpreted by the author.

\begin{tabular}{ll}
\hline Scientific Journal & Scientific Area \\
\hline Agriculture (Switzerland) & Agriculture \\
BioScience & Biology \\
Computers and Electronics in Agriculture & Agriculture \\
Disaster risk reduction & Risks \\
Ecological Economics & Ecology \\
Ecological Indicators & Ecology \\
Ecological Informatics & Ecology \\
Ecological Modelling, & Ecology \\
Ecology and Society & Ecology \\
Ecosystem Services & Ecosystems \\
Ecosystems and People & Ecosystems \\
Environmental Impact Assessment Review & Environmental Science \\
Environmental Monitoring and Assessment & Environmental Science \\
Environmental Science and Policy & Environmental Science \\
Forest Ecology and Management & Forestry \\
Forest Systems & Forestry \\
Forests & Forestry \\
Frontiers in Earth Science & Environmental Science \\
Frontiers in Ecology and the Environment & Ecology \\
Global Environmental Change & Environmental Science \\
Human Ecology & Ecology \\
International Journal of Wildland Fire & Wildfire \\
Journal of Environmental Management & Environmental Science \\
Land & Planning \\
Land Use Policy & Planning \\
Landscape and Urban Planning & Planning \\
PLoS ONE & Various \\
Regional Environmental Change & Environmental Science \\
Science of the Total Environment & Environmental Science \\
Sustainability (Switzerland) & Sustainability \\
Urban Forestry and Urban Greening & Forestry \\
Water (Switzerland) & Water \\
\hline & \\
\hline
\end{tabular}

\section{Appendix B}

Table A2. Complete table of the 52 studies selected for the literature review, with their main characteristics. The method categories are Social Science Techniques (SST), Qualitative Approach (QA), Historical Perspective (HP), Statistical Approach (SA), Quantitative Modelling (QM), Agent-Based Models (ABM), Vulnerability Analysis (VA). See the Method and Instruments Section for more information.

\begin{tabular}{|c|c|c|c|c|c|c|c|c|}
\hline Authors & $\begin{array}{c}\text { Pubblication } \\
\text { Year }\end{array}$ & Journal & $\begin{array}{c}\text { Pubblication } \\
\text { Type }\end{array}$ & $\begin{array}{c}\text { Authors' } \\
\text { Geography }\end{array}$ & $\begin{array}{l}\text { Area of } \\
\text { Interest }\end{array}$ & $\begin{array}{c}\text { Scale of } \\
\text { Analysis: } \\
\text { Extent }\end{array}$ & $\begin{array}{c}\text { Scale of } \\
\text { Analysis: } \\
\text { Resolution }\end{array}$ & $\begin{array}{c}\text { Method } \\
\text { Cate- } \\
\text { gory }\end{array}$ \\
\hline Pais et al. [81] & 2020 & $\begin{array}{c}\text { Ecosystem } \\
\text { Services }\end{array}$ & $\begin{array}{l}\text { Research } \\
\text { article }\end{array}$ & $\begin{array}{c}\text { Canada, } \\
\text { Portugal, } \\
\text { Spain }\end{array}$ & $\begin{array}{l}\text { Portugal, } \\
\text { Spain }\end{array}$ & mesoscale & $30 \mathrm{~m}^{2}$ & QM \\
\hline Oliveira and Zêzere [82] & 2020 & $\begin{array}{c}\text { Journal of } \\
\text { Environmental } \\
\text { Management }\end{array}$ & $\begin{array}{l}\text { Research } \\
\text { article }\end{array}$ & Portugal & Portugal & national & civil parishes & SA \\
\hline Colantoni et al. [61] & 2020 & Land & $\begin{array}{l}\text { Research } \\
\text { article }\end{array}$ & Italy & $\begin{array}{c}\text { Greece, focus } \\
\text { on Attica }\end{array}$ & mesoscale & prefectures & SA \\
\hline Balzan et al. [34] & 2019 & $\begin{array}{c}\text { Ecosystems and } \\
\text { People }\end{array}$ & $\begin{array}{l}\text { Research } \\
\text { article }\end{array}$ & $\begin{array}{c}\text { Malta, Spain, } \\
\text { France, Serbia, } \\
\text { Portugal, UK, } \\
\text { Greece, } \\
\text { Germany }\end{array}$ & $\begin{array}{l}\text { Mediterranean } \\
\text { region }\end{array}$ & supranational & / & QA \\
\hline Higuera et al. [42] & 2019 & BioScience & Review & USA & $\begin{array}{c}\text { no study area, } \\
\text { general and } \\
\text { speculative }\end{array}$ & mesoscale & / & QA \\
\hline
\end{tabular}


Table A2. Cont.

\begin{tabular}{|c|c|c|c|c|c|c|c|c|}
\hline Authors & $\begin{array}{c}\text { Pubblication } \\
\text { Year }\end{array}$ & Journal & $\begin{array}{c}\text { Pubblication } \\
\text { Type }\end{array}$ & $\begin{array}{l}\text { Authors' } \\
\text { Geography }\end{array}$ & $\begin{array}{l}\text { Area of } \\
\text { Interest }\end{array}$ & $\begin{array}{l}\text { Scale of } \\
\text { Analysis: } \\
\text { Extent }\end{array}$ & $\begin{array}{l}\text { Scale of } \\
\text { Analysis: } \\
\text { Resolution }\end{array}$ & $\begin{array}{c}\text { Method } \\
\text { Cate- } \\
\text { gory }\end{array}$ \\
\hline Kefalas et al. [83] & 2019 & $\begin{array}{l}\text { Landscape and } \\
\text { Urban Planning }\end{array}$ & $\begin{array}{l}\text { Research } \\
\text { article }\end{array}$ & Greece & Ionian islands & mesoscale & $30 \times 30 \mathrm{~m}$ & SA \\
\hline Zambon et al. [62] & 2019 & $\begin{array}{l}\text { Agriculture } \\
\text { (Switzerland) }\end{array}$ & $\begin{array}{l}\text { Research } \\
\text { article }\end{array}$ & $\begin{array}{l}\text { Italy, Spain, } \\
\text { Czech } \\
\text { Republic }\end{array}$ & Spain & mesoscale & municipialities & SA \\
\hline Carlucci et al. [63] & 2019 & $\begin{array}{l}\text { Sustainability } \\
\text { (Switzerland) }\end{array}$ & $\begin{array}{l}\text { Research } \\
\text { article }\end{array}$ & Italy & Italy & national & nation & SA \\
\hline Ferrara et al. [36] & 2019 & $\begin{array}{l}\text { Science of the } \\
\text { Total } \\
\text { Environment }\end{array}$ & $\begin{array}{l}\text { Research } \\
\text { article }\end{array}$ & Italy & Italy & national & municipality & SA \\
\hline $\begin{array}{l}\text { Martínez-López et al. } \\
\text { [80] }\end{array}$ & 2019 & $\begin{array}{l}\text { Science of the } \\
\text { Total } \\
\text { Environment }\end{array}$ & $\begin{array}{l}\text { Research } \\
\text { article }\end{array}$ & $\begin{array}{c}\text { Spain, USA, } \\
\text { Netherlands, } \\
\text { UK }\end{array}$ & $\begin{array}{l}\text { Spain, US, } \\
\text { Africa }\end{array}$ & mesoscale & $200 \mathrm{~m}-1 \mathrm{~km}$ & QM \\
\hline Stavi [84] & 2019 & $\begin{array}{c}\text { Water } \\
\text { (Switzerland) }\end{array}$ & Review & Israel & / & various & / & QA \\
\hline Bodonirina et al. [35] & 2018 & Forests & $\begin{array}{l}\text { Research } \\
\text { article }\end{array}$ & $\begin{array}{c}\text { Madagascar, } \\
\text { Switzerland, } \\
\text { Canada, } \\
\text { France }\end{array}$ & Madagascar & mesoscale & / & SST \\
\hline Olander et al. [45] & 2018 & $\begin{array}{l}\text { Ecological } \\
\text { Indicators }\end{array}$ & $\begin{array}{l}\text { Research } \\
\text { article }\end{array}$ & USA & / & mesoscale & / & QA \\
\hline Díaz et al. [76] & 2018 & $\begin{array}{l}\text { Ecosystem } \\
\text { Services, }\end{array}$ & $\begin{array}{l}\text { Research } \\
\text { article }\end{array}$ & Chile, Spain & Chile & mesoscale & basin & QM \\
\hline Fischer [46] & 2018 & $\begin{array}{l}\text { Landscape and } \\
\text { Urban Planning }\end{array}$ & $\begin{array}{l}\text { Research } \\
\text { article }\end{array}$ & USA & / & mesoscale & / & QA \\
\hline Moskwa et al. [47] & 2018 & $\begin{array}{c}\text { Environmental } \\
\text { Science \& } \\
\text { Policy, }\end{array}$ & $\begin{array}{l}\text { Research } \\
\text { article }\end{array}$ & Australia & Australia & mesoscale & / & SST \\
\hline Power et al. [38] & 2018 & $\begin{array}{l}\text { Frontiers in } \\
\text { Earth Science }\end{array}$ & Short Survey & USA & USA & mesoscale & not specified & $\mathrm{HP}$ \\
\hline Githumbi et al. [73] & 2018 & $\begin{array}{l}\text { Frontiers in } \\
\text { Earth Science }\end{array}$ & $\begin{array}{l}\text { Research } \\
\text { article }\end{array}$ & $\begin{array}{l}\text { UK, Sweden, } \\
\text { Tanzania, } \\
\text { South Africa }\end{array}$ & Kenya & mesoscale & $\begin{array}{c}0.5 \times 0.5 \\
\text { degrees }\end{array}$ & $\begin{array}{l}\mathrm{HP}+ \\
\mathrm{ABM}\end{array}$ \\
\hline Mancini et al. [64] & 2018 & $\begin{array}{c}\text { Environmental } \\
\text { Impact } \\
\text { Assessment } \\
\text { Review }\end{array}$ & $\begin{array}{l}\text { Research } \\
\text { article }\end{array}$ & Italy & Italy & national & municipality & SA \\
\hline Ferrara et al. [65] & 2018 & $\begin{array}{c}\text { Environmental } \\
\text { Monitoring and } \\
\text { Assessment }\end{array}$ & $\begin{array}{l}\text { Research } \\
\text { article }\end{array}$ & Italy, Greece & $\begin{array}{l}\text { Greece, focus } \\
\text { on Attica }\end{array}$ & mesoscale & / & SA \\
\hline Palaiologou et al. [85] & 2018 & $\begin{array}{l}\text { International } \\
\text { Journal of } \\
\text { Wildland Fire }\end{array}$ & $\begin{array}{l}\text { Research } \\
\text { article }\end{array}$ & Greece, USA & Greece & mesoscale & not specified & QM \\
\hline Luvuno [43] & 2018 & $\begin{array}{l}\text { Sustainability } \\
\text { (Switzerland) }\end{array}$ & Review & $\begin{array}{l}\text { South Africa, } \\
\text { Sweden }\end{array}$ & Africa & supranational & / & QA \\
\hline Charnley et al. [58] & 2017 & $\begin{array}{l}\text { Ecology and } \\
\text { Society }\end{array}$ & $\begin{array}{l}\text { Research } \\
\text { article }\end{array}$ & USA & USA & mesoscale & $\begin{array}{l}\text { individual } \\
\text { landscape } \\
\text { decision units } \\
\text { (IDUs), } \\
\text { ranging from } 3 \\
\text { to } 10 \text { ha in } \\
\text { size. }\end{array}$ & $\mathrm{ABM}$ \\
\hline Bautista et al. [48] & 2017 & $\begin{array}{c}\text { Journal of } \\
\text { Environmental } \\
\text { Management }\end{array}$ & $\begin{array}{l}\text { Research } \\
\text { article }\end{array}$ & $\begin{array}{l}\text { Spain, France, } \\
\text { USA }\end{array}$ & Spain & mesoscale & / & SST \\
\hline Kline et al. [71] & 2017 & $\begin{array}{l}\text { Ecology and } \\
\text { Society }\end{array}$ & $\begin{array}{l}\text { Research } \\
\text { article }\end{array}$ & USA & USA & mesoscale & / & $\mathrm{ABM}$ \\
\hline Nguyen et al. [49] & 2017 & Land Use Policy & $\begin{array}{l}\text { Research } \\
\text { article }\end{array}$ & Australia & Vietnam & mesoscale & / & SST \\
\hline Ríos-Pena et al. [86] & 2017 & $\begin{array}{l}\text { Journal of } \\
\text { Environmental } \\
\text { Management }\end{array}$ & $\begin{array}{l}\text { Research } \\
\text { article }\end{array}$ & $\begin{array}{l}\text { Spain, } \\
\text { Germany }\end{array}$ & Spain & mesoscale & $1 \mathrm{~km} \times 1 \mathrm{~km}$ & SA \\
\hline $\begin{array}{c}\text { Monzón-Alvarado and } \\
\text { Keys [57] }\end{array}$ & 2017 & $\begin{array}{c}\text { Regional } \\
\text { Environmental } \\
\text { Change }\end{array}$ & $\begin{array}{l}\text { Research } \\
\text { article }\end{array}$ & Mexico, USA & Mexico & mesoscale & / & SST \\
\hline Spies et al. [32] & 2017 & $\begin{array}{l}\text { Ecology and } \\
\text { Society }\end{array}$ & $\begin{array}{l}\text { Research } \\
\text { article }\end{array}$ & USA & USA & mesoscale & $30 \mathrm{~m}$ & $\mathrm{ABM}$ \\
\hline Hulse et al. [72] & 2016 & $\begin{array}{l}\text { Landscape and } \\
\text { Urban Planning }\end{array}$ & $\begin{array}{l}\text { Research } \\
\text { article }\end{array}$ & USA & USA & mesoscale & $\begin{array}{l}\text { Integrated } \\
\text { Decison Units, } \\
0.9 \text { ha in } \\
\text { average }\end{array}$ & $\mathrm{ABM}$ \\
\hline Salvati et al. [66] & 2016 & $\begin{array}{l}\text { Journal of } \\
\text { Environmental } \\
\text { Management, }\end{array}$ & $\begin{array}{l}\text { Research } \\
\text { article }\end{array}$ & $\begin{array}{c}\text { Greece, } \\
\text { Tunisia, Italy, } \\
\text { Spain, } \\
\text { Morocco, } \\
\text { Turkey, } \\
\text { Netherlands, } \\
\text { UK, }\end{array}$ & $\begin{array}{c}\text { Spain, Greece, } \\
\text { Turkey, } \\
\text { Tunisia, } \\
\text { Morocco }\end{array}$ & microscale & $\begin{array}{c}\text { field } \\
(0.5-20 \mathrm{ha})\end{array}$ & SA \\
\hline
\end{tabular}


Table A2. Cont.

\begin{tabular}{|c|c|c|c|c|c|c|c|c|}
\hline Authors & $\begin{array}{c}\text { Pubblication } \\
\text { Year }\end{array}$ & Journal & $\begin{array}{c}\text { Pubblication } \\
\text { Type }\end{array}$ & $\begin{array}{l}\text { Authors' } \\
\text { Geography }\end{array}$ & $\begin{array}{l}\text { Area of } \\
\text { Interest }\end{array}$ & $\begin{array}{l}\text { Scale of } \\
\text { Analysis: } \\
\text { Extent }\end{array}$ & $\begin{array}{c}\text { Scale of } \\
\text { Analysis: } \\
\text { Resolution }\end{array}$ & $\begin{array}{c}\text { Method } \\
\text { Cate- } \\
\text { gory }\end{array}$ \\
\hline Santos et al. [87] & 2016 & $\begin{array}{l}\text { Ecological } \\
\text { Informatics }\end{array}$ & $\begin{array}{l}\text { Research } \\
\text { article }\end{array}$ & $\begin{array}{c}\text { Portugal, } \\
\text { Switzerland, } \\
\text { South Africa, } \\
\text { Germany }\end{array}$ & $\begin{array}{l}\text { Portugal, } \\
\text { Spain }\end{array}$ & mesoscale & $\begin{array}{l}\text { patches (unit } \\
\text { cells) } 1 \text { ha }\end{array}$ & $\mathrm{ABM}$ \\
\hline Fischer et al. [44] & 2016 & $\begin{array}{l}\text { Frontiers in } \\
\text { Ecology and the } \\
\text { Environment }\end{array}$ & Review & USA, Canada & USA & not defined & / & QA \\
\hline Tedim et al. [30] & 2016 & $\begin{array}{l}\text { Disaster Risk } \\
\text { Reduct }\end{array}$ & $\begin{array}{l}\text { Research } \\
\text { article }\end{array}$ & $\begin{array}{l}\text { Portugal, Italy, } \\
\text { Greece }\end{array}$ & Portugal & mesoscale & / & QA \\
\hline Acha and Newing [52] & 2015 & Human Ecology & $\begin{array}{l}\text { Research } \\
\text { article }\end{array}$ & UK & Spain & microscale & / & SST \\
\hline Salvati et al. [70] & 2015 & $\begin{array}{l}\text { Sustainability } \\
\text { (Switzerland) }\end{array}$ & $\begin{array}{l}\text { Research } \\
\text { article }\end{array}$ & Italy & Italy & mesoscale & not specified & VA \\
\hline Aretano et al. [37] & 2015 & $\begin{array}{l}\text { Ecological } \\
\text { Modelling }\end{array}$ & $\begin{array}{l}\text { Research } \\
\text { article }\end{array}$ & Italy & Italy & mesoscale & not declared & VA \\
\hline $\begin{array}{c}\text { Santibáñez-Andrade } \\
\text { et al. [75] }\end{array}$ & 2015 & $\begin{array}{l}\text { Ecological } \\
\text { Indicators, }\end{array}$ & $\begin{array}{l}\text { Research } \\
\text { article }\end{array}$ & Mexico & Mexico & mesoscale & $\begin{array}{c}21 \\
\text { environmental } \\
\text { units }\end{array}$ & QM \\
\hline Salvati and Carlucci [67] & 2015 & $\begin{array}{l}\text { Ecological } \\
\text { Economics }\end{array}$ & $\begin{array}{l}\text { Research } \\
\text { article }\end{array}$ & Italy & Italy & national & municipality & SA \\
\hline Maru et al. [54] & 2014 & $\begin{array}{l}\text { Global } \\
\text { Environmental } \\
\text { Change, }\end{array}$ & $\begin{array}{l}\text { Research } \\
\text { article }\end{array}$ & $\begin{array}{c}\text { Australia, } \\
\text { Brazil, } \\
\text { Botzwana }\end{array}$ & $\begin{array}{c}\text { Australia, } \\
\text { Brazil, } \\
\text { Botzwana }\end{array}$ & mesoscale & / & $\begin{array}{l}\mathrm{SST}+ \\
\mathrm{QA}\end{array}$ \\
\hline Fetzel et al. [77] & 2014 & $\begin{array}{l}\text { Ecological } \\
\text { Economics, }\end{array}$ & $\begin{array}{l}\text { Research } \\
\text { article }\end{array}$ & $\begin{array}{l}\text { Austria, New } \\
\text { Zeland }\end{array}$ & New Zealand & national & not specified & QM \\
\hline Coughlan [88] & 2014 & $\begin{array}{c}\text { Forest Ecology } \\
\text { and } \\
\text { Management }\end{array}$ & $\begin{array}{l}\text { Research } \\
\text { article }\end{array}$ & USA & France & $\begin{array}{l}\text { microscale } \\
\left(125 \mathrm{~km}^{2}\right)\end{array}$ & not specified & SA \\
\hline Porto et al. [59] & 2014 & PLoS ONE & Review & Portugal & Portugal & $\begin{array}{l}\text { mesoscale } \\
\text { (simulated } \\
\text { landscape) }\end{array}$ & 1 ha & QM \\
\hline Spies et al. [31] & 2014 & $\begin{array}{l}\text { Ecology and } \\
\text { Society }\end{array}$ & $\begin{array}{l}\text { Research } \\
\text { article }\end{array}$ & USA & USA & mesoscale & $\begin{array}{l}\text { units of } 3 \text { ha } \\
\text { average }\end{array}$ & $\mathrm{ABM}$ \\
\hline Salvati and Ferrara [68] & 2014 & $\begin{array}{l}\text { Urban Forestry } \\
\text { and Urban } \\
\text { Greening }\end{array}$ & $\begin{array}{l}\text { Research } \\
\text { article }\end{array}$ & Italy & Greece & mesoscale & not specified & SA \\
\hline Prior and Eriksen [51] & 2013 & $\begin{array}{c}\text { Global } \\
\text { Environmental } \\
\text { Change }\end{array}$ & $\begin{array}{l}\text { Research } \\
\text { article }\end{array}$ & $\begin{array}{c}\text { Australia, } \\
\text { Switzerland }\end{array}$ & Australia & mesoscale & / & SST \\
\hline Collins et al. [39] & 2013 & $\begin{array}{l}\text { Journal of } \\
\text { Environmental } \\
\text { Management, }\end{array}$ & $\begin{array}{l}\text { Research } \\
\text { article }\end{array}$ & USA, Portugal & Portugal & national & / & QM \\
\hline Stellmes et al. [89] & 2013 & $\begin{array}{l}\text { Land Use } \\
\text { Policy, }\end{array}$ & $\begin{array}{l}\text { Research } \\
\text { article }\end{array}$ & Germany & Spain & national & $1 \mathrm{~km}^{2}$ & SA \\
\hline $\begin{array}{c}\text { Costafreda-Aumedes } \\
\text { et al. [90] }\end{array}$ & 2013 & Forest Systems & $\begin{array}{l}\text { Research } \\
\text { article }\end{array}$ & Spain & Spain & national & $\begin{array}{c}10 \mathrm{~km} \times \\
10 \mathrm{~km}\end{array}$ & SA \\
\hline Papadimitriou [91] & 2012 & $\begin{array}{l}\text { Computers and } \\
\text { Electronics in } \\
\text { Agriculture }\end{array}$ & $\begin{array}{l}\text { Research } \\
\text { article }\end{array}$ & Greece & $\begin{array}{l}\text { Mediterrean } \\
\text { environment }\end{array}$ & supranational & / & QM \\
\hline Zucca et al. [74] & 2012 & $\begin{array}{l}\text { Ecological } \\
\text { Indicators, }\end{array}$ & $\begin{array}{l}\text { Research } \\
\text { article }\end{array}$ & Italy & $\begin{array}{l}\text { Sub-Saharian } \\
\text { Africa }\end{array}$ & supranational & $\begin{array}{l}\text { Different for } \\
\text { each indicator }\end{array}$ & QM \\
\hline Kalabokidis et al. [53] & 2008 & $\begin{array}{l}\text { Environmental } \\
\text { Science and } \\
\text { Policy }\end{array}$ & $\begin{array}{l}\text { Research } \\
\text { article }\end{array}$ & Greece, USA & Greece & mesoscale & / & SST \\
\hline
\end{tabular}

\section{References}

1. Convention on Biological Diversity. Available online: https://www.cbd.int/forest/definitions.shtml\#: \{\}:text=A\%20forest $\% 20$ ecosystem \%20can\%20be,key\%20component\%20of\%20the\%20system (accessed on 3 February 2021).

2. European Forest Ecosystems: State and Trends; European Environment Agency: Luxembourg, 2016; ISBN 978-92-9213-728-1.

3. Global Forest Resources Assessment 2020: Key Findings; FAO: Rome, Italy, 2020; ISBN 978-92-5-132581-0.

4. Doerr, S.H.; Santín, C. Global Trends in Wildfire and Its Impacts: Perceptions versus Realities in a Changing World. Philos. Trans. R. Soc. B Biol. Sci. 2016, 371, 20150345. [CrossRef]

5. San-Miguel-Ayanz, J.; Durrant, T.; Boca, R.; Libertà, G.; Branco, A.; de Rigo, D.; Ferrari, D.; Maianti, P.; Artés Vivancos, T.; Oom, D.; et al. Forest Fires in Europe, Middle East and North Africa 2018; JRC Technical Report; Publications Office of the European Union: Luxembourg, 2018.

6. Füssel, H.M.; Kristensen, P.; Jol, A.; Marx, A.; Hildén, M. Climate Change, Impacts and Vulnerability in Europe 2016: An Indicator-Based Report; EEA Report; Publications Office of the European Union: Luxembourg, 2017.

7. De Rigo, D.; Libertà, G.; Houston Durrant, T.; Artés Vivancos, T.; San-Miguel-Ayanz, J. Forest Fires Danger Extremes in Europe under Climate Change: Variability and Uncertainty; JRC Technical Report; Publications Office of the European Union: Luxembourg, 2017.

8. Agee, J.K.; Bahro, B.; Finney, M.A.; Omi, P.N.; Sapsis, D.B.; Skinner, C.N.; van Wagtendonk, J.W.; Phillip Weatherspoon, C. The Use of Shaded Fuelbreaks in Landscape Fire Management. For. Ecol. Manag. 2000, 127, 55-66. [CrossRef] 
9. Ager, A.; Vaillant, N. A Comparison of Landscape Fuel Treatment Strategies to Mitigate Wildland Fire Risk in the Urban Interface and Preserve Old Forest Structure. For. Ecol. Manag. 2010, 259, 1556-1570. [CrossRef]

10. Graham, R.T.; Harvey, A.E.; Jain, T.B.; Tonn, J.R. The Effects of Thinning and Similar Stand Treatments on Fire Behavior in Western Forests. Gen. Tech. Rep. 1999, 463. [CrossRef]

11. Vilar del Hoyo, L.; Martín Isabel, M.P.; Martínez Vega, F.J. Logistic Regression Models for Human-Caused Wildfire Risk Estimation: Analysing the Effect of the Spatial Accuracy in Fire Occurrence Data. Eur. J. For. Res. 2011, 130, 983-996. [CrossRef]

12. Gallardo, M.; Gómez, I.; Vilar, L.; Martínez-Vega, J.; Martín, M.P. Impacts of Future Land Use/Land Cover on Wildfire Occurrence in the Madrid Region (Spain). Reg. Environ. Chang. 2016, 16, 1047-1061. [CrossRef]

13. Müller, M.; Vilà Vilardell, L.; Vacik, H.; Mayer, C.; Mayr, S.; Carrega, P.; Duche, Y.; Lahaye, S.; Böttcher, F.; Maier, H.; et al. Forest Fires in the Alps. State of Knowledge, Future Challenges and Options for an Integrated Fire Management; White Paper for Policy Makers; EUSALP Action Group 8: Vienna, Austria, 2020.

14. Pezzatti, G.B.; Zumbrunnen, T.; Bürgi, M.; Ambrosetti, P.; Conedera, M. Fire Regime Shifts as a Consequence of Fire Policy and Socio-Economic Development: An Analysis Based on the Change Point Approach. For. Policy Econ. 2013, 29, 7-18. [CrossRef]

15. Aldersley, A.; Murray, S.J.; Cornell, S.E. Global and Regional Analysis of Climate and Human Drivers of Wildfire. Sci. Total Environ. 2011, 409, 3472-3481. [CrossRef]

16. Ganteaume, A.; Camia, A.; Jappiot, M.; San-Miguel-Ayanz, J.; Long-Fournel, M.; Lampin, C. A Review of the Main Driving Factors of Forest Fire Ignition Over Europe. Environ. Manag. 2013, 51, 651-662. [CrossRef]

17. Martínez-Fernández, J.; Chuvieco, E.; Koutsias, N. Modelling Long-Term Fire Occurrence Factors in Spain by Accounting for Local Variations with Geographically Weighted Regression. Nat. Hazards Earth Syst. Sci. 2013, 13, 311-327. [CrossRef]

18. Rodrigues, M.; Jiménez, A.; de la Riva, J. Analysis of Recent Spatial-Temporal Evolution of Human Driving Factors of Wildfires in Spain. Nat. Hazards 2016, 84, 2049-2070. [CrossRef]

19. Glaser, M.; Krause, G.; Ratter, B.M.W.; Welp, M. Human-Nature Interactions in the Anthropocene: Potentials of Social-Ecological Systems Analysis; Routledge: London, UK, 2012; ISBN 978-1-136-33766-6.

20. Schlüter, M.; Müller, B.; Frank, K. The Potential of Models and Modeling for Social-Ecological Systems Research: The Reference Frame ModSES. Ecol. Soc. 2019, 24. [CrossRef]

21. Zingraff-Hamed, A.; Noack, M.; Greulich, S.; Schwarzwälder, K.; Wantzen, K.M.; Pauleit, S. Model-Based Evaluation of Urban River Restoration: Conflicts between Sensitive Fish Species and Recreational Users. Sustainability 2018, 10, 1747. [CrossRef]

22. Thober, J.; Müller, B.; Groeneveld, J.; Grimm, V. Agent-Based Modelling of Social-Ecological Systems: Achievements, Challenges, and a Way Forward. J. Artif. Soc. Soc. Simul. 2017, 20. [CrossRef]

23. Egli, L.; Weise, H.; Radchuk, V.; Seppelt, R.; Grimm, V. Exploring Resilience with Agent-Based Models: State of the Art, Knowledge Gaps and Recommendations for Coping with Multidimensionality. Ecol. Complex. 2019, 40, 100718. [CrossRef]

24. Filatova, T.; Verburg, P.H.; Parker, D.C.; Stannard, C.A. Spatial Agent-Based Models for Socio-Ecological Systems: Challenges and Prospects. Environ. Model. Softw. 2013, 45, 1-7. [CrossRef]

25. Cote, M.; Nightingale, A.J. Resilience Thinking Meets Social Theory: Situating Social Change in Socio-Ecological Systems (SES) Research. Prog. Hum. Geogr. 2012, 36, 475-489. [CrossRef]

26. Binder, C.; Hinkel, J.; Bots, P.; Pahl-Wostl, C. Comparison of Frameworks for Analyzing Social-Ecological Systems. Ecol. Soc. 2013, 18. [CrossRef]

27. Liberati, A.; Altman, D.G.; Tetzlaff, J.; Mulrow, C.; Gøtzsche, P.C.; Ioannidis, J.P.A.; Clarke, M.; Devereaux, P.J.; Kleijnen, J.; Moher, D. The PRISMA Statement for Reporting Systematic Reviews and Meta-Analyses of Studies That Evaluate Health Care Interventions: Explanation and Elaboration. PLoS Med. 2009, 6, e1000100. [CrossRef]

28. Gusenbauer, M.; Haddaway, N.R. Which Academic Search Systems Are Suitable for Systematic Reviews or Meta-Analyses? Evaluating Retrieval Qualities of Google Scholar, PubMed, and 26 Other Resources. Res. Synth. Methods 2020, 11, 181-217. [CrossRef] [PubMed]

29. Wohlin, C.; Mendes, E.; Felizardo, K.R.; Kalinowski, M. Guidelines for the Search Strategy to Update Systematic Literature Reviews in Software Engineering. Inf. Softw. Technol. 2020, 127, 106366. [CrossRef]

30. Tedim, F.; Leone, V.; Xanthopoulos, G. A Wildfire Risk Management Concept Based on a Social-Ecological Approach in the European Union: Fire Smart Territory. Int. J. Disaster Risk Reduct. 2016, 18, 138-153. [CrossRef]

31. Spies, T.; White, E.; Kline, J.; Fischer, A.; Ager, A.; Bailey, J.; Bolte, J.; Koch, J.; Platt, E.; Olsen, C.; et al. Examining Fire-Prone Forest Landscapes as Coupled Human and Natural Systems. Ecol. Soc. 2014, 19. [CrossRef]

32. Spies, T.; White, E.; Ager, A.; Kline, J.; Bolte, J.; Platt, E.; Olsen, K.; Pabst, R.; Barros, A.; Bailey, J.; et al. Using an Agent-Based Model to Examine Forest Management Outcomes in a Fire-Prone Landscape in Oregon, USA. Ecol. Soc. 2017, 22. [CrossRef]

33. Haggett, P. Geografia, Scienze della Terra; Zanichelli: Bologna, Italy, 2004; Volume 1, ISBN 978-88-08-07757-8.

34. Balzan, M.V.; Pinheiro, A.M.; Mascarenhas, A.; Morán-Ordóñez, A.; Ruiz-Frau, A.; Carvalho-Santos, C.; Vogiatzakis, I.N.; Arends, J.; Santana-Garcon, J.; Roces-Díaz, J.V.; et al. Improving Ecosystem Assessments in Mediterranean Social-Ecological Systems: A DPSIR Analysis. Ecosyst. People 2019, 15, 136-155. [CrossRef]

35. Bodonirina, N.; Reibelt, L.M.; Stoudmann, N.; Chamagne, J.; Jones, T.G.; Ravaka, A.; Ranjaharivelo, H.V.F.; Ravonimanantsoa, T.; Moser, G.; De Grave, A.; et al. Approaching Local Perceptions of Forest Governance and Livelihood Challenges with Companion Modeling from a Case Study around Zahamena National Park, Madagascar. Forests 2018, 9, 624. [CrossRef] 
36. Ferrara, C.; Salvati, L.; Corona, P.; Romano, R.; Marchi, M. The Background Context Matters: Local-Scale Socioeconomic Conditions and the Spatial Distribution of Wildfires in Italy. Sci. Total Environ. 2019, 654, 43-52. [CrossRef] [PubMed]

37. Aretano, R.; Semeraro, T.; Petrosillo, I.; De Marco, A.; Pasimeni, M.R.; Zurlini, G. Mapping Ecological Vulnerability to Fire for Effective Conservation Management of Natural Protected Areas. Ecol. Model. 2015, 295, 163-175. [CrossRef]

38. Power, M.J.; Codding, B.F.; Taylor, A.H.; Swetnam, T.W.; Magargal, K.E.; Bird, D.W.; O'Connell, J.F. Human Fire Legacies on Ecological Landscapes. Front. Earth Sci. 2018, 6. [CrossRef]

39. Collins, R.D.; de Neufville, R.; Claro, J.; Oliveira, T.; Pacheco, A.P. Forest Fire Management to Avoid Unintended Consequences: A Case Study of Portugal Using System Dynamics. J. Environ. Manag. 2013, 130, 1-9. [CrossRef] [PubMed]

40. Gentile, A.R. From National Monitoring to European Reporting: The EEA Framework for Policy Relevant Environmental Indicators. In Proceedings of the International Seminar on Indicators for Assessing Desertification in the Mediterranean, Porto Torres, Italy, 18-20 September 1998; pp. 18-20.

41. Smeets, E.; Weterings, R. Environmental Indicators: Typology and Overview; European Environment Agency: Copenhagen, Denmark, 1999 ; p. 19.

42. Higuera, P.E.; Metcalf, A.L.; Miller, C.; Buma, B.; McWethy, D.B.; Metcalf, E.C.; Ratajczak, Z.; Nelson, C.R.; Chaffin, B.C.; Stedman, R.C.; et al. Integrating Subjective and Objective Dimensions of Resilience in Fire-Prone Landscapes. BioScience 2019, 69, 379-388. [CrossRef]

43. Luvuno, L.; Biggs, R.; Stevens, N.; Esler, K. Woody Encroachment as a Social-Ecological Regime Shift. Sustainability 2018, $10,2221$. [CrossRef]

44. Fischer, A.P.; Spies, T.A.; Steelman, T.A.; Moseley, C.; Johnson, B.R.; Bailey, J.D.; Ager, A.A.; Bourgeron, P.; Charnley, S.; Collins, B.M.; et al. Wildfire Risk as a Socioecological Pathology. Front. Ecol. Environ. 2016, 14, 276-284. [CrossRef]

45. Olander, L.P.; Johnston, R.J.; Tallis, H.; Kagan, J.; Maguire, L.A.; Polasky, S.; Urban, D.; Boyd, J.; Wainger, L.; Palmer, M. Benefit Relevant Indicators: Ecosystem Services Measures That Link Ecological and Social Outcomes. Ecol. Indic. 2018, 85, 1262-1272. [CrossRef]

46. Fischer, A.P. Forest Landscapes as Social-Ecological Systems and Implications for Management. Landsc. Urban Plan. 2018, 177, 138-147. [CrossRef]

47. Moskwa, E.; Bardsley, D.K.; Robinson, G.M.; Weber, D. Generating Narratives on Bushfire Risk and Biodiversity Values to Inform Environmental Policy. Environ. Sci. Policy 2018, 89, 30-40. [CrossRef]

48. Bautista, S.; Llovet, J.; Ocampo-Melgar, A.; Vilagrosa, A.; Mayor, Á.G.; Murias, C.; Vallejo, V.R.; Orr, B.J. Integrating Knowledge Exchange and the Assessment of Dryland Management Alternatives-A Learning-Centered Participatory Approach. J. Environ. Manag. 2017, 195, 35-45. [CrossRef]

49. Nguyen, H.H.; Dargusch, P.; Moss, P.; Aziz, A.A. Land-Use Change and Socio-Ecological Drivers of Wetland Conversion in Ha Tien Plain, Mekong Delta, Vietnam. Land Use Policy 2017, 64, 101-113. [CrossRef]

50. Etienne, M. (Ed.) Companion Modelling: A Participatory Approach to Support Sustainable Development; Springer: Amsterdam, The Netherlands, 2014; ISBN 978-94-017-8556-3.

51. Prior, T.; Eriksen, C. Wildfire Preparedness, Community Cohesion and Social-Ecological Systems. Glob. Environ. Chang. 2013, 23, 1575-1586. [CrossRef]

52. Acha, A.; Newing, H.S. Cork Oak Landscapes, Promised or Compromised Lands? A Case Study of a Traditional Cultural Landscape in Southern Spain. Hum. Ecol. 2015, 43, 601-611. [CrossRef]

53. Kalabokidis, K.; Iosifides, T.; Henderson, M.; Morehouse, B. Wildfire Policy and Use of Science in the Context of a Socio-Ecological System on the Aegean Archipelago. Environ. Sci. Policy 2008, 11, 408-421. [CrossRef]

54. Maru, Y.T.; Stafford Smith, M.; Sparrow, A.; Pinho, P.F.; Dube, O.P. A Linked Vulnerability and Resilience Framework for Adaptation Pathways in Remote Disadvantaged Communities. Glob. Environ. Chang. 2014, 28, 337-350. [CrossRef]

55. FAO-ECE-ILO Public Participation in Forestry in Europe and North America; Report of the FAO/ECE/ILO Joint Committee Team of Specialists on Participation in Forestry; International Labour Office: Geneva, Switzerland, 2000; p. 137.

56. Bonan, G. "Di tutti e di nessuno": I beni comunali nel Veneto preunitario. Quad. Stor. 2017, 52, 445-470.

57. Monzón-Alvarado, C.M.; Keys, E. Synergistic Vulnerabilities: Climate Variability and Fire Management Policy Increase Farming Challenges in Southeastern Mexico. Reg. Environ. Chang. 2017, 17, 489-500. [CrossRef]

58. Charnley, S.; Spies, T.; Barros, A.; White, E.; Olsen, K. Diversity in Forest Management to Reduce Wildfire Losses: Implications for Resilience. Ecol. Soc. 2017, 22. [CrossRef]

59. Porto, M.; Correia, O.; Beja, P. Optimization of Landscape Services under Uncoordinated Management by Multiple Landowners. PLoS ONE 2014, 9. [CrossRef]

60. Calkin, D.E.; Cohen, J.D.; Finney, M.A.; Thompson, M.P. How Risk Management Can Prevent Future Wildfire Disasters in the Wildland-Urban Interface. Proc. Natl. Acad. Sci. USA 2014, 111, 746-751. [CrossRef]

61. Colantoni, A.; Egidi, G.; Quaranta, G.; D'Alessandro, R.; Vinci, S.; Turco, R.; Salvati, L. Sustainable Land Management, Wildfire Risk and the Role of Grazing in Mediterranean Urban-Rural Interfaces: A Regional Approach from Greece. Land $2020,9,21$. [CrossRef]

62. Zambon, I.; Cerdà, A.; Cudlin, P.; Serra, P.; Pili, S.; Salvati, L. Road Network and the Spatial Distribution of Wildfires in the Valencian Community (1993-2015). Agriculture 2019, 9, 100. [CrossRef] 
63. Carlucci, M.; Zambon, I.; Colantoni, A.; Salvati, L. Socioeconomic Development, Demographic Dynamics and Forest Fires in Italy, 1961-2017: A Time-Series Analysis. Sustainability 2019, 11, 1305. [CrossRef]

64. Mancini, L.D.; Corona, P.; Salvati, L. Ranking the Importance of Wildfires' Human Drivers through a Multi-Model Regression Approach. Environ. Impact Assess. Rev. 2018, 72, 177-186. [CrossRef]

65. Ferrara, C.; Marchi, M.; Carlucci, M.; Mavrakis, A.; Corona, P.; Salvati, L. The 2007 Crisis and Greek Wildfires: A Multivariate Analysis of Suppression Times. Environ. Monit. Assess. 2018, 190, 714. [CrossRef]

66. Salvati, L.; Kosmas, C.; Kairis, O.; Karavitis, C.; Acikalin, S.; Belgacem, A.; Solé-Benet, A.; Chaker, M.; Fassouli, V.; Gokceoglu, C.; et al. Assessing the Effectiveness of Sustainable Land Management Policies for Combating Desertification: A Data Mining Approach. J. Environ. Manag. 2016, 183, 754-762. [CrossRef]

67. Salvati, L.; Carlucci, M. Towards Sustainability in Agro-Forest Systems? Grazing Intensity, Soil Degradation and the Socioeconomic Profile of Rural Communities in Italy. Ecol. Econ. 2015, 112, 1-13. [CrossRef]

68. Salvati, L.; Ferrara, A. Do Land Cover Changes Shape Sensitivity to Forest Fires in Peri-Urban Areas? Urban For. Urban Green. 2014, 13, 571-575. [CrossRef]

69. Lung, T.; Lavalle, C.; Hiederer, R.; Dosio, A.; Bouwer, L.M. A Multi-Hazard Regional Level Impact Assessment for Europe Combining Indicators of Climatic and Non-Climatic Change. Glob. Environ. Chang. 2013, 23, 522-536. [CrossRef]

70. Salvati, L.; Ferrara, A.; Tombolini, I.; Gemmiti, R.; Colantoni, A.; Perini, L. Desperately Seeking Sustainability: Urban Shrinkage, Land Consumption and Regional Planning in a Mediterranean Metropolitan Area. Sustainability 2015, 7, 11980-11997. [CrossRef]

71. Kline, J.; White, E.; Fischer, A.; Steen-Adams, M.; Charnley, S.; Olsen, C.; Spies, T.; Bailey, J. Integrating Social Science into Empirical Models of Coupled Human and Natural Systems. Ecol. Soc. 2017, 22. [CrossRef]

72. Hulse, D.; Branscomb, A.; Enright, C.; Johnson, B.; Evers, C.; Bolte, J.; Ager, A. Anticipating Surprise: Using Agent-Based Alternative Futures Simulation Modeling to Identify and Map Surprising Fires in the Willamette Valley, Oregon USA. Landsc. Urban Plan. 2016, 156, 26-43. [CrossRef]

73. Githumbi, E.N.; Kariuki, R.; Shoemaker, A.; Courtney-Mustaphi, C.J.; Chuhilla, M.; Richer, S.; Lane, P.; Marchant, R. Pollen, People and Place: Multidisciplinary Perspectives on Ecosystem Change at Amboseli, Kenya. Front. Earth Sci. 2018, 5. [CrossRef]

74. Zucca, C.; Peruta, R.D.; Salvia, R.; Sommer, S.; Cherlet, M. Towards a World Desertification Atlas. Relating and Selecting Indicators and Data Sets to Represent Complex Issues. Ecol. Indic. 2012, 15, 157-170. [CrossRef]

75. Santibáñez-Andrade, G.; Castillo-Argüero, S.; Vega-Peña, E.V.; Lindig-Cisneros, R.; Zavala-Hurtado, J.A. Structural Equation Modeling as a Tool to Develop Conservation Strategies Using Environmental Indicators: The Case of the Forests of the Magdalena River Basin in Mexico City. Ecol. Indic. 2015, 54, 124-136. [CrossRef]

76. Díaz, M.E.; Figueroa, R.; Alonso, M.L.S.; Vidal-Abarca, M.R. Exploring the Complex Relations between Water Resources and Social Indicators: The Biobío Basin (Chile). Ecosyst. Serv. 2018, 31, 84-92. [CrossRef]

77. Fetzel, T.; Gradwohl, M.; Erb, K.-H. Conversion, Intensification, and Abandonment: A Human Appropriation of Net Primary Production Approach to Analyze Historic Land-Use Dynamics in New Zealand 1860-2005. Ecol. Econ. 2014, 97, 201-208. [CrossRef]

78. Erb, K.-H.; Haberl, H.; Jepsen, M.R.; Kuemmerle, T.; Lindner, M.; Müller, D.; Verburg, P.H.; Reenberg, A. A Conceptual Framework for Analysing and Measuring Land-Use Intensity. Curr. Opin. Environ. Sustain. 2013, 5, 464-470. [CrossRef]

79. Haberl, H.; Erb, K.-H.; Plutzar, C.; Fischer-Kowalski, M.; Krausmann, F.; Hak, T.; Moldan, B.; Dahl, A.L. Human Appropriation of Net Primary Production (HANPP) as Indicator for Pressures on Biodiversity. In Sustainability Indicators: A Scientific Assessment; Island Press: Washinton, DC, USA, 2007; pp. 271-288.

80. Martínez-López, J.; Bagstad, K.J.; Balbi, S.; Magrach, A.; Voigt, B.; Athanasiadis, I.; Pascual, M.; Willcock, S.; Villa, F. Towards Globally Customizable Ecosystem Service Models. Sci. Total Environ. 2019, 650, 2325-2336. [CrossRef] [PubMed]

81. Pais, S.; Aquilué, N.; Campos, J.; Sil, Â.; Marcos, B.; Martínez-Freiría, F.; Domínguez, J.; Brotons, L.; Honrado, J.P.; Regos, A. Mountain Farmland Protection and Fire-Smart Management Jointly Reduce Fire Hazard and Enhance Biodiversity and Carbon Sequestration. Ecosyst. Serv. 2020, 44, 101143. [CrossRef]

82. Oliveira, S.; Zêzere, J.L. Assessing the Biophysical and Social Drivers of Burned Area Distribution at the Local Scale. J. Environ. Manag. 2020, 264, 110449. [CrossRef]

83. Kefalas, G.; Kalogirou, S.; Poirazidis, K.; Lorilla, R.S. Landscape Transition in Mediterranean Islands: The Case of Ionian Islands, Greece 1985-2015. Landsc. Urban Plan. 2019, 191, 103641. [CrossRef]

84. Stavi, I. Wildfires in Grasslands and Shrublands: A Review of Impacts on Vegetation, Soil, Hydrology, and Geomorphology. Water 2019, 11, 1042. [CrossRef]

85. Palaiologou, P.; Ager, A.; Nielsen-Pincus, M.; Evers, C.; Kalabokidis, K. Using Transboundary Wildfire Exposure Assessments to Improve Fire Management Programs: A Case Study in Greece. Int. J. Wildland Fire 2018, 27. [CrossRef]

86. Ríos-Pena, L.; Kneib, T.; Cadarso-Suárez, C.; Marey-Pérez, M. Predicting the Occurrence of Wildfires with Binary Structured Additive Regression Models. J. Environ. Manag. 2017, 187, 154-165. [CrossRef]

87. Santos, M.; Ferreira, D.; Bastos, R.; Vicente, J.; Honrado, J.; Kueffer, C.; Kull, C.A.; Berger, U.; Cabral, J.A. Linking Landscape Futures with Biodiversity Conservation Strategies in Northwest Iberia-A Simulation Study Combining Surrogates with a Spatio-Temporal Modelling Approach. Ecol. Inform. 2016, 33, 85-100. [CrossRef]

88. Coughlan, M.R. Farmers, Flames, and Forests: Historical Ecology of Pastoral Fire Use and Landscape Change in the French Western Pyrenees, 1830-2011. For. Ecol. Manag. 2014, 312, 55-66. [CrossRef] 
89. Stellmes, M.; Röder, A.; Udelhoven, T.; Hill, J. Mapping Syndromes of Land Change in Spain with Remote Sensing Time Series, Demographic and Climatic Data. Land Use Policy 2013, 30, 685-702. [CrossRef]

90. Costafreda-Aumedes, S.; Garcia-Martin, A.; Vega-Garcia, C. The Relationship between Landscape Patterns and Human-Caused Fire Occurrence in Spain. For. Syst. 2013, 22, 71. [CrossRef]

91. Papadimitriou, F. Artificial Intelligence in Modelling the Complexity of Mediterranean Landscape Transformations. Comput. Electron. Agric. 2012, 81, 87-96. [CrossRef] 